\title{
PENGARUH MASUKNYA BUDAYA ASING TERHADAP PELESTARIAN KEBUDAYAAN TARI TRADISIONAL WAYANG TOPENG MALANGAN DI MALANG RAYA, JAWA TIMUR
}

\author{
Yolanda Priska Purnama ${ }^{1}$ \\ Aprilia Rachmadian ${ }^{2}$ \\ Program Diploma Kepariwisataan Universitas Merdeka Malang 2 \\ Jl. Bandung No. 1 Malang
}

Korespodensi dengan Penulis:

Aprilia Rachmadian: Telp: 087859307262

E-mail: apriliarach@gmail.com

\begin{abstract}
The objective in this study is to determine the influence of foreign culture to culture preservation of Malangan Puppet mask Traditional Dance in Malang, East Java and to know the supporting factors and obstacles which is considered to be very dominant. The research location is in Pakisaji Malang. This research can be categorized in qualitative research because the data obtained from the questionnaire while research approaches including observation and interviews. In this study, the population is all the travelers who had seen the puppet dance performance mask malangan, while the number of respondents used in this study were 10 respondents. The conclusions of this research is Malangan Puppet mask Traditional Dance has a history and a strong potential to be tourist attraction in Malang, by doing coordination with dance studio in Malang to raise the local culture.
\end{abstract}

Keywords: Cultural Preservation, Traditional Dance, Malangan Puppet mask.

Pengembangan pariwisata di Undang-Undang No.9 Tahun 1990. Hal Indonesia pada dasarnya menggunakan konsep pariwisata budaya (cultural ini dilakukan tentunya dengan tourism) seperti telah ditetapkan dalam pertimbangan bahwa Indonesia memiliki potensi seni dan budaya yang 
beraneka ragam yang tersebar pada tiap

Daerah Tujuan Wisata (DTW) di Indonesia. Jadi, pariwisata yang kita kembangkan adalah pariwisata budaya. Dalam hal ini, seni budaya yang beraneka ragam di beberapa DTW itu dijadikan sebagai daya tarik utama untuk menarik wisatawan datang ke Negara kita.

Atas dasar itu, kiranya wajar apabila setiap langkah dalam pengembangan pariwisata diharapkan selalu memperhatikan terpeliharanya seni dan budaya bangsa yang dijadikan aset Pariwisata Indonesia. Dengan demikian, perlu ada tanggung jawab moral bagi mereka yang mengambil kebijakan di lapangan untuk selalu menggunakan potensi seni dan budaya yang dimiliki untuk bermacam-macam kegiatan, mulai dari bentuk bangunan (architecture), cindera mata (souvenirs), bahan-bahan promosi (promotion materials), makanan dan minuman (food and beverages), terutama dalam penyajiannya.

Tujuan utama dari semua itu, tidak lain adalah untuk menciptakan image dan lebih penting lagi dengan cara itu Pariwisata Indonesia akan memiliki ciri yang khas atau identitasnya sendiri berbeda dengan apa yang dimiliki oleh Negara-negara lain.

Dalam konteks ini, dapat dikatakan bahwa pariwisata sebagai suatu industri lebih bersifat padat karya (labor intensive) dan sekaligus berfungsi sebagai katalisator dalam pembangunan (agent of development) dan mempercepat proses pemerataan pendapatan masyarakat (re-distribution of income). Kita mengetahui bahwa kedatangan wisman jelas akan meningkatkan perolehan devisa bagi Negara dan dalam beberapa periode terakhir ini ternyata devisa sektor pariwisata telah menduduki peringkat kedua setelah devisa minyak bumi dan gas alam.

Kebudayaan daerah pada saat ini terasa kritis karena tergeser oleh kebudayaan modern dari barat. Perlahan masyarakat mulai meninggalkan kebudayaan daerah yang sebenarnya memiliki makna yang dalam. Masyarakat menggangap kebudayaan daerah merupakan suatu pemikiran kuno yang tidak tepat pada 
konteks zaman sekarang ini. Budaya tidak lagi sebagai filter terhadap perkembangan zaman tetapi menjadi sebuah kenangan belaka. Tidak seluruhnya masyarakat meninggalkan kebudayaan, tetapi generasi penerus yang kian menyusut karena mayoritas beranggapan bahwa budaya lokalitas tidak selaras dengan kondisi saat ini yang cenderung mengarah pada budaya modern.

Pemuda saat ini lebih condong kepada budaya modern karena mengganggap lebih serasi pada jiwa mereka dan merupakan tren pada saat ini. Anggapan keserasian budaya modern pada jiwa pemuda sekarang menimbulkan penerimaan secara langsung kebudayaan dari luar tanpa adanya penyaringan dari Lokalitas Kebudayaan. Perkembangan budaya modern saat ini tidak dapat ditolak, melainkan disaring dengan budaya lokalitas yang kental pada setiap daerah.

Lokalitas budaya pada setiap daerah semakin lama semakin kritis dengan berkembangnya kebudayaan modern, kebudayaan tersebut telah mengalihkan pandangan masyarakat tentang kebudayaan lokalitas mereka. Kebudayaan lokalitas Malang yakni “Wayang Topeng Malangan (Topeng Malang)",yang hampir ditinggalkan oleh masyarakat Malang Raya sendiri. Hal ini terjadi karena tidak ada generasi penerus pembuatan Topeng Malangan yang merupakan identitas Malang Raya. Gaya kesenian ini adalah wujud pertemuan tiga budaya (Jawa Tengahan, Madura, dan Tengger). Hal tersebut terjadi karena Malang memiliki tiga sub-kultur, yaitu sub-kultur budaya Jawa Tengahan yang hidup di lereng gunung Kawi, sub-kultur Madura di lereng gunung Arjuna, dan sub-kultur Tengger sisa budaya Majapahit di lereng gunung Bromo-Semeru. Etnik masyarakat Malang terkenal religius, dinamis, suka bekerja keras.

Dengan sepeninggalnya Mbah Karimun yang merupakan satu-satunya tokoh budaya Topeng Malangan, Kebudayaan Seni Topeng Malangan dalam beberapa tahun kedepan akan mati jika tetap tidak adanya respon dari masyarakat Malang Raya untuk menjaga identitas budaya lokal Malang. 
Hal ini perlu adanya tanggapan dan tindakan serius dari Pemerintah Kota dan Kabupaten Malang untuk menangani identitas Budaya Malang yang sudah kritis. Perlu adanya suatu wadah atau tempat untuk memberikan pelatihan dan edukasi terhadap masyarakat Malang Raya untuk menghidupkan kembali Kesenian Topeng Malangan ini. Dengan harapan identitas Malang Raya tetap dikenal oelh daera-daerah lain di Indonesia maupun Mancanegara.

Di Kota Malang terdapat tempat yang merupakan sarana apresiasi Budaya Jawa Timur yaitu “Taman Krida Budaya Jawa Timur" yang hanya menampilkan budaya khas Jawa Timur seperti Ludruk, Ketoprak, Wayang Orang, Wayang Kulit, Reog, Kuda Lumping dan Sendra Tari. Realita pada saat ini Taman Krida Budaya beralih fungsi menjadi tempat sebuah acara, seperti resepsi pernikahan. Selain itu Taman Krida Budaya tersebut merupakan apresiasi Budaya tingkat Provinsi, dan tidak berisi budaya khas Malang.
Wayang Topeng Malang merupakan budaya khas asli dari Wilayah Malang. Wayang Topeng Malang saat ini terletak di Desa Kedungmonggo, Kecamatan PakisajiKabupaten Malang,dan juga mulai berkembang di sekitar Candi Jago Desa Jago Kecamatan Tumpang-Kabupaten Malang. Kondisinya saat ini kurang mendapat perhatian dari Pemerintah Kabupaten Malang, terlihat tidak adanya fasilitas yang memadai untuk melestarikan serta memberikan pengenalan terhadap masyarakat yang saat ini telah condong kepada budaya modern.

\section{KEBUDAYAAN PARIWISATA}

Menurut Drs. H. Oka A. Yoeti, Mba, dkk (2006:26-27) , dalam bagian ini dibicarakan dua hal, yaitu :

a.Wisata budaya sebagai suatu jenis wisata,

b.Pengaruh wisata terhadap kebudayaan.

Hal yang pertama, wisata budaya diartikan sebagai jenis kegiatan pariwisata yang objeknya adalah kebudayaan. Ini dibedakan dari minat- 
minat khusus lain, seperti wisata alam, dan wisata petualangan. Namun demikian tidak berarti bahwa seorang wisatawan tidak bisa memiliki lebih dari satu program wisata.

Objek "daya tarik" wisata budaya itu dapat berkisar pada beberapa hal, seperti : kesenian (seni rupa dan segala bentuk seni pertunjukan), tata busana, boga, upacara adat, demonstrasi kekebalan dan komunikasi dengan alam ghaib, lingkungan binaan, serta keterampilanketerampilan khusus fungsional seperti membuat alat-alat, dll. Objek-objek itu tidak jarang dikemas khusus bagi penyajian untuk turis, dengan maksud agar menjadi lebih menarik. Dalam hal inilah seringkali terdapat kesenjangan selera antara kalangan seni dan kalangan industri pariwisata. Kompromi-kompromi seringkali harus diambil. Namun yang memerlukan kehati-hatian lebih besar adalah niatan untuk "mengemas" sajian-sajian yang bermakna religi bagi masyarakat pemiliknya. Perlu dijaga betul agar disatu sisi, tidak terjadi pelecehan terhadap praktek religi yang bersangkutan, dan disisi lain tidak mendorong orang ke jalan musyrik.

Mengenai pengaruh pariwisata terhadap kebudayaan pada masyarakat tuan rumah dapat dibedakan dua perkara, yaitu :

a. Pengaruh dalam kehidupan ekonomi apabila kegiatan pariwisata itu dapat meningkatkan kesempatan kerja dan tingkat kemakmuran, dan

b. Pengaruh kehadiran wisatawan mancanegara dengan kebiasaan dan busananya yang sebenarnya asing bagi masyrakat dan tuan rumah.

Kemakmuran, apabila tidak dipandu baik-baik dengan suatu sikap budaya yang benar akan dapat mengembangkan nilai budaya yang berubah, misalnya dari adat kekeluargaan dan gotong royong kearah sikap"semua bisa dibeli asal ada uang". Disamping itu usaha industri pariwisata itu memunculkan para "makelar" yang mencari untuk sebesar-besarnya atas tetesan keringat orang lain yang bekerja di garis depan.

Kehadiran wisatawan dengan segala adat kebiasaannya tidak jarang juga menimbulkan efek "meniru" pada 
penduduk setempat. Apa yang ditiru itu dapat baik dapat buruk, dan dalam jangka waktu tertentu dapat menggeser nilai-nilai budaya setempat.

\section{DAMPAK POSITIF DAN NEGATIF MASUKNYA BUDAYA ASING}

Pengaruh budaya asing disebabkan oleh kontak kebudayaan. Semakin intensif hubungan atau interaksi dengan masyarakat yang berbudaya, sehingga akan berpotensi menimbulkan dampak bagi budaya asli yang sudah ada, berikut dampak yang dihasilkan :

\section{Dampak positif :}

1. Berkembangnya ilmu pengetahuan dan juga teknologi, sehingga masyarakat bisa mengetahui informasi yang ada di Indonesia dan di dunia

2. Tingkat kehidupan yang lebih baik dari segi ekonomi, dan lain sebagainya.

3. Sikap yang lebih baik seperti, disiplin, sigap dan lain sebagainya

4. Bermunculan produk-produk luar negeri yang diproduksi di Indonesia, membuat terciptanya lapangan pekerjaan dan meningkatkan taraf hidup masyarakat Indonesia
5. Dapat memperkaya keberagaman budaya Indonesia bila dimanfaatkan dengan baik

\section{Dampak negatif :}

1.Menggunakan busana yang tidak sesuai dengan norma yang berlaku di Indonesia

2.Materialistis atau budaya hidup bermewah-mewahan

3.Tersingkirnya produk dalam negeri, karena masyarakat cenderung memilih ke barang impor yang anggapannya memiliki merk dan kualitas tinggi.

4.Dengan masuknya budaya asing tersebut, maka akan menyebabkan lemahnya nilai-nilai budaya bangsa, dan masyarakat lama-kelamaan akan meninggalkan budaya Indonesia yang dianggapnya sudah kuno.

5.Terjadinya perubahan budaya, misalnya pada masa lalu masyarakat akan mengunjungi rumahnya apabila ada hal yang ingin disampaikan, akan tetapi karena sudah ada handphone dan tekhnologi canggih maka dapat melalui pesan singkat atau telephone. Ini akan membuat hubungan antara keduanya tidak sedekat apabila langsung bertemu (bersilaturahmi). 
6.Minat terhadap budaya Indonesia semakin berkurang karena beralih ke budaya barat, sebagai contoh anak muda akan lebih minat dengan tarian modern (dance) daripada tari-tarian tradisional (misal : tari wayang topeng malangan).

7.Anak-anak Indonesia lebih sudak bermain game online daripada mainanmainan tradisional seperti main kelereng, gangsingan, dan lain sebagainya.

\section{TARI TRADISIONAL WAYANG TOPENG MALANGAN}

Tari Topeng atau Wayang Topeng merupakan dramatari yang menceritakan tentang roman Panji. Roman atau Cerita Panji merupakan karya sastra klasik yang cukup dikenal luas oleh masyarakat Jawa, Indonesia, bahkan Asia Tenggara, disamping cerita Ramayana dan Mahabarata. Sebagai karya sastra klasik, cerita ini ditransformasikan ke dalam berbagai karya baru seni dan budaya (Manuaba dkk, 2013:53). Secara historis, Cerita Panji muncul pada tengah pertama abad ke-13, pada masa kerajaan Singosari, namun Winarno \& Widyatmoko (1998:241) menyebutkan bahwa seni topeng diperkirakan sudah muncul sejak zaman kerajaan Kediri pada abad ke-12, dan berkembang mulai zaman keemasan kerajaan Majapahit. Relief Candi Penataran yang dibangun pada tahun 1369 yang menggambarkan adegan Panji Kartala oleh Panakawan Prasanta setidaknya dapat menjadi bukti bahwa Cerita Panji sudah populer di Jawa Timur pada abad ke-14 (Sumaryono, 2011:18).

Menurut Hariyono (1988:130), pertunjukan wayang topeng Malangan awalnya berkembang di desa Kedungmonggo dan desa Polowijen (Kecamatan Blimbing, Malang, Jawa Timur), disebut dengan topeng Jabung, yang kemudian dikenal sebagai kesenian topeng Malang. Namun Pigeaud (dalam Supriyanto \& Adi Pramono, 1997, Hidajat, 2005:270) mengungkapkan bahwa pada akhir abad ke-19 tercatat adanya wayang topeng yang dipertunjukkan di pendopo kabupaten Malang, yaitu waktu pemerintahan A.A. Surya Adiningrat (1898-1934). Ia juga mencatat 
terdapat perkumpulan wayang topeng di bagian Malang Selatan pada tahun 1930-an, seperti di Sanggreng, Jenggala, Wijiamba, dan Turen.

Wayang topeng Malangan ini mementaskan cerita Panji seperti Sayembara Sada Lanang, Walang Sumirang, Rabine Panji, Laire Nogo Taun, dan Jenggala Mbangun Candi, dimana tokoh-tokoh utama yang sering muncul antara lain, Panji Asmarabangun, Dewi Sekartaji, Raden Gunungsari, Klana Sewandana, dan Bapang Jayasentika. Pigeaud juga melanjutkan, bahwa pada tahun 1956 atau 1957, wayang topeng Malangan juga sering dipertunjukkan di pendopo kabupaten, karena pada saat itu bupati Malang, R. Djapan sangat berminat pada kesenian lokal.

Oleh para ahli kebudayaan (dalam Hariyono, 1988:130), topeng Malangan ini dihubungkan dengan bentuk drama tari bertopeng pada abad ke-12 yang dikenal dengan nama raket, atapukan, atau wayang wang. Karimun, salah seorang ahli waris dari $\mathrm{R}$. Sungging Mubengkoro, yang masih keturunan dari Sunan Brawijaya VII
(Raja Majapahit terakhir, 1498-1518) memimpin kelompok topeng Asmorobangun atau Sanggar Asmorobangun yang didirikan sejak tahun 1931 di desa Kedungmonggo, dan mulai dikenal masyarakat luas sebagai pengukir topeng sejak tahun 1970-an. Saat ini mbah Karimoen sudah wafat dan digantikan oleh putranya yang bernama Tri Handoyo, menjadi punggawa Sanggar Asmorobangun.

Onghokham

(1972:115-119) mengungkapkan bahwa topeng Malangan disebut sebagai "Malangan" karena memang memiliki ciri khas yang berbeda dengan topeng yang berasal dari Jawa Tengah atau Bali. Topeng yang dikenakan oleh penari/pemain wayang topeng Malangan, ditahan di kepala penari dengan seutas tali yang tersambung pada topeng, bukan menggunakan sepotong kulit yang digigit di mulut. Berbeda dengan gaya "halus" dari Jawa Tengah, topeng Malang terbuat dari kayu yang tebal dan berat, dibentuk dengan bagian dagu lebih persegi, tulang pipi yang cukup menonjol (tinggi), dan kaya akan ukiran. Mahkota yang terletak di kepala 
bagian depan juga penuh dengan ukiran yang cukup kompleks (isen-isen). Kumis dari figur yang tergolong "figur gagah", kurang lebih terdapat 21 figur, selalu diukir, sedangkan pada topeng Jawa Tengah hanya di-cat saja, atau terbuat dari rambut asli atau palsu. Topeng Malang kebanyakan mulutnya selalu lebih tertutup daripada Jawa Tengah yang lebih terbuka. Tidak hanya pada topeng sebagai properti dalam pertunjukan wayang topeng Malangan, namun pada kostum juga cukup banyak memiliki perbedaan dengan daerah lain di Indonesia, begitu juga dengan struktur pertunjukan wayang, dan juga tarinya, namun perbedaan tersebut akan dijelaskan kemudian karena penelitian ini memang terfokus pada topengnya saja, sebagai aspek rupa/kriya dalam pertunjukan seni tradisi wayang topeng Malangan.

\section{METODE PENELITIAN}

\section{IDENTIFIKASI DAN DEFINISI}

\section{KONSEPTUAL VARIABEL}

Berdasarkan judul dan latar belakang penelitian yang telah dijelaskan terdahulu maka penelitian ini lebih memfokuskan pada sinergitas antara variabel $X$ dan variabel $Y$ yang mana penulisan akan mengemukakan uraian secara singkat mengenai variabel-variabel yang bersangkutan dengan masalah yang diteliti :

1. Variabel $(X) \quad$ : $\quad$ Pengaruh Masuknya Budaya Asing

2. Variabel $(\mathrm{Y}) \quad$ :Pelestarian

Kebudayaan Tari Tradisional Wayang Topeng Malangan di Malang Raya.

1. Variabel $(X)$ :

Pengaruh Masuknya Budaya Asing mencerminkan wujud globalisasi dan modernisasi yang dapat berdampak positif dan negatif bagi kebudayaan Indonesia,

\section{Variabel $(\mathrm{Y})$ :}

Pelestarian Kebudayaan Tari Tradisional Wayang Topeng Malangan di Malang Raya digunakan sebagai wadah untuk melatih kembali kreatifitas anak muda untuk menghidupkan kembali tari topeng wayangan menjadi salah satu Icon di Malang Raya dengan syarat-syarat atraksi.

Syarat yang dimaksud disini adalah : 
1. Atraksi itu sendiri harus dalam keadaan baik tanpa menghilangkan nilai keasliannya.

2. Cara penyajiaanya harus tepat dengan mengatur perspektif ruang,waktu dan sosial budaya.

3. Dapat memberikan keunikan tersendiri sehingga membuat para wisatawan bisa menikmati khas budaya dari tarian ini.

Adapun ruang lingkup dalam penelitian ini, penulis meneliti mengenai berbagai permasalahan yang berhubungan dengan Tari Wayang Topeng Malangan sebagai atraksi wisata Icon Malang Raya dilihat dari bentuk, fungsi dan makna pelaksanaanya dalam mendukung perluasan seni budaya yang telah ada, sehingga Tari Wayang Topeng Malangan dapat menjadi sebuah atraksi khas wisata di Malang Raya, Jawa Timur.

Penelitian dilakukan di Jl. Prajurit Slamet, Dusun Kedung Monggo, Desa Karang Pandan, Kecamatan Pakisaji, Kabupaten Malang. Dusun Kedung nMonggo berjarak 14 kilo meter dari pusat Kota Malang.
Sumber data adalah tempat orang atau benda dimana peneliti dapat mengamati, bertanya dan mencari tahu hal-hal yang berkenaan dengan variabel yang diteliti.

Lofland dan Lexy Maleong (2000:12), mengatakan bahwa "Sumber data utama dalam penelitian kualitatif adalah kata dan tindakan, selebihnya adalah data tambahan seperti dokumen dan lain-lain".

1. Data Primer yaitu data yang diperoleh secara langsung dari pihak pertama (responden) seperti melalui wawancara langsung dengan informan yang mengetahui tentang tari tradisional wayang topeng malangan.

2. Data Sekunder yaitu data yang diperoleh dari pihak-pihak tertentu dan bukan dari pihak pertama (Marzuki, 1997:56). Data sekunder dalam penelitian ini misalnya data yang diperoleh dari Dinas Kebudayaan dan Pariwisata, data tersebut berupa data jumlah kunjungan wisatawan, jumlah penduduk, brosur, serta buku-buku lengkap mengenai data yang teliti. 
Dalam penelitian ini pengumpulan data dilakukan dengan beberapa cara,yaitu:

1. Observasi yaitu pengumpulan data dengan cara pengamatan secara langsung di objek penelitian untuk mendapatkan gambaran yang jelas tentang objek penelitan. Untuk melengkapi observasi tersebut, penulis melakukan pengambilan gambar dengan menggunakan kamera.

2. Wawancara yaitu teknik pengumpulan data yang dilakukan dengan tanya jawab yang mendalam kepada informan dengan menggunakan daftar pertanyaan yang telah disusun sebelumnya. Informan yaitu Bapak Tri Handoyo selaku Punggawa Sanggar Asmorobangun sekaligus anak dari Maestro Wayang Topeng Malangan Mbah Karimoen, dan sejumlah informan yang memiliki informasi mengenai sejarah pelaksanaan tari wayang topeng malangan.

3. Kuisioner yaitu pengumpulan data dengan cara menyebarkan daftar pertanyaan kepada wisatawan untuk memperoleh persepsi mereka terhadap tari tradisional wayang topeng malangan sebagai atraksi khas wisata Malang Raya di Jawa Timur. Penyebaran ini akan diberikan secara acak kepada wisatawan yang ditemui peneliti selama mengadakan penelitian dipertunjukan tari tradisional wayang topeng malangan.

4. Studi Kepustakaan yaitu pengumpulan data dengan cara mengambil data dari hasil penelitian yang dilakukan sebelumnya, makalah pariwisata, browsing internet, serta bahan-bahan tertulis lainnya yang berhubungan dengan daya tarik tari tradisional wayang topeng malangan.

Dalam penelitian ini, peneliti menggunakan analisis deskriptif kualitatif. Analisis yang dilakukan dengan memanfaatkan beberapa jenis data yang diperoleh baik dari data primer maupun dari data sekunder, baik dari hasil wawancara, hasil pengamatan langsung, hasil catatan, hasil rekaman, hasil dokumentasi dan lain sebagainya (Maleong, 2000-190). 
Dengan mengetahui aspek-aspek tersebut, kemudian bagaimana pentingnya tari tradisional wayang topeng malangan sebagai atraksi khas wisata Malang Raya untuk meningkatkan kunjungan wisatawan dan meningkatkan SDM pemuda pemudi untuk mengembangkan tarian ini dan menjadi pengrajin topeng malangan.

\section{PEMBAHASAN}

Seperti tema yang diangkat dalam penulisan Artikel ini yaitu “Pengaruh Masuknya Budaya Asing Terhadap Pelestarian Kebudayaan Tari Tradisional Wayang Topeng Malangan di Kota Malang, Jawa Timur" untuk menanyakan seputar "Bagaimana Cara Mempertahankan dan Melestarikan Kebudayaan Tari Tradisional Wayang Topeng Malangan sebagai Icon Malang Raya? Dan Bagaimana Cara Menarik Minat Wisatawan Terhadap Tari Wayang Topeng Malangan sebagai Atraksi Khas Wisata Malang Raya?.
BUKTI MASALAH

Pengembangan Tari Tradisional Wayang Topeng Malangan sangat berpengaruh pada perkembangan pariwisata di Malang Raya, sesuai dengan kebutuhan atau minat wisatawan domestik maupun wisatawan asing. Hal ini telah disinggung secara langsung dalam penelitian diatas, dan diperoleh hasil bahwa :

1. Tari Tradisional Wayang Topeng Malangan sebenarnya sangat menarik untuk atraksi khas wisata Malang Raya, tetapi sayangnya jarang sekali ada yang peduli bahkan dari masyarakat Malang Raya sendiri.

2. Kurangnya sarana dan prasarana yang ada di Padepokan Seni Topeng Asmarabangun.

3. Kurang adanya peminat dari masyarakat untuk belajar menari atau belajar membuat topeng. 


\section{AKIBAT MASALAH}

Berdasarkan poin-poin yang ada diatas, maka penulis dapat menyimpulkan bahwa :

1. Kurangnya wisatawan yang tahu tentang tari tradisional khas Malang Raya.

2. Tari wayang topeng malangan diadakan setiap satu bulan sekali setiap hari minggu kliwon malam senin legi, disitu seharusnya pihak terkait bisa memberikan alternatif pertunjukan tari disanggar lain.

3. Kurangnya sarana dan prasarana yang ada dipadepokan seni topeng asamarabangun, sehingga tidak bisa menampung banyak penonton.

4. Kurangnya minat dari pemuda pemudi untuk belajar menari tari wayang topeng malangan.

5. Kurangnya minat wisatawan untuk melihat pertunjukan tari wayang topeng malangan.

EVALUASI ALTERNATIF

\section{PENYELESAIAN MASALAH}

1. Mulai menggalakkan promosi melalui berbagai sosial media tentang pertunjukan tari wayang topeng malangan.

Kelebihan : Dapat meningkatkan jumlah wisatawan domestik maupun mancanegara untuk menyaksikan pertunjukan tari wayang topeng malangan.

Kekurangan : Diperlukannya bantuan investor untuk mendukung dalam berbagai segi (keuangan, SDM, dan sebagainya) sehingga tari wayang topeng malangan tetap terjaga keaslian budayanya dan teroganisir dengan baik.

2. Memasukkan serangkaian paket tour tentang edukasi tari wayang topeng malangan dan tarian tradisional yang lain.

Kelebihan : Nilai tambah untuk kita semua jika bisa mempelajari taritarian khas malang dan juga mengerti sejarah akan tarian tersebut.

Kekurangan :Pada umumnya peminat untuk mempelajari tarian tradisional sangatlah sedikit, apalagi dikalangan anak muda. Mereka lebih sering mempelajari hal-hal yang berbau modern dan kebarat-baratan. 
3. Menambah sarana dan prasarana yang ada agar bisa menampung banyak pengunjung jika ada pertunjukan tari.

Kelebihan :Para pengunjung bisa mendapatkan posisi duduk yang nyaman ketika melihat pertunjukan tari tersebut tanpa harus berdesakdesakan atau berdiri.

Kekurangan:Diperlukannya investor untuk merenovasi atau membuka lahan baru untuk membangun ruangan yang luas sesuai dengan perhitungan pengunjung.

4. Mencoba mengenalkan tari wayang topeng malangan ke berbagai sekolah atau universitas untuk menarik minat pemuda pemudi untuk belajar menari.

Kelebihan : Adanya regenerasi pemuda pemudi untuk melestarikan tari tradisional wayang topeng malangan

Kekurangan : Kurangnya minat pemuda pemudi untuk berkecimpung dalam dunia seni tari tradisional.

5.Membuat suatu rangkaian atraksi wisata khas Malang Raya, dan memasukkan tari wayang topeng malangan sebagai salah satu pembuka acara.

Kelebihan :Bisa menjadi atraksi wisata khas Malang Raya yang menampilkan tarian tradisional wayang topeng malangan sehingga para wisatawan akan mengerti bahwa Malang juga mempunyai tarian sendiri.

Kekurangan :Dibutuhkan kerjasama dengan berbagai pihak instansi pemerintah dan travel-travel untuk memasarkan paket tour ini.

\section{KESIMPULAN}

Dari paparan atau penjelasan diatas, dengan judul artikel "Pengaruh Masuknya Budaya Asing Terhadap Pelestarian Kebudayaan Tari Tradisional Wayang Topeng Malangan Di Malang Raya, Jawa Timur" maka penulis menyimpulkan bahwa posisi tari tradisional wayang topeng malangan tergeser dengan adanya tarian modern. Antusias dari masyrakat sekitar sanggar tari asmarabangun cukup baik namun kurang adanya sarana prasarana pendukung yang 
layak untuk membuat mereka meminati belajar menari maupun membuat topeng wayang itu sendiri. Sumber daya masyarakat Malang Raya tentang Tari Wayang Topeng Malangan sangatlah minim, sehingga banyak sanggar-sanggar tari wayang topeng malangan ditempat lainnya tidak mampu mengadakan pertunjukan karena kurangnya kesadaran lokalitas budaya.

\section{SARAN}

Untuk pengembangan lebih lanjut, maka penulis akan memberikan saran terkait pelestarian kebudayaan tari wayang topeng malangan untuk membantu dimasa yang akan datang :

1. Perlu mengadakan negoisasi kerjasama antar pihak Pemerintah Kota Malang dan Kabupaten Malang untuk bersama-sama mengangkat kesenian Wayang Topeng Malangan agar masyarakat Malang Raya mengetahui lokalitas budaya yang ada.

2. Diperlukannya investor untuk membantu mengelola, mempromosikan dan menjaga kesenian Wayang Topeng Malangan agar tetap utuh sebagai identitas budaya Malang Raya

\section{DAFTAR PUSTAKA}

Drs. H. Oka A. Yoeti, 1990. Komersialisasi Seni Budaya Dalam Pariwisata. Angkasa Bandung : Bandung.

Drs. H. Oka A. Yoeti, 1991. Pengantar Ilmu Pariwisata. Bandung : Aksara.

Drs. H. Oka A. Yoeti, MBA,dkk 2006. "Pariwisata Budaya Masalah dan Solusinya". PT Pradnya Paramita Jakarta : Jakarta

Hubner, Ira. Pariwisata Indonesia : menuju keputusan lebih baik Vol 2 PUSLIT Kepariwisataan Lembaga Penelitian ITB, Bandung, 1998

Inskeep, Edward. 1991. Tourism Planning : An Integrated and Suistanable Development Approach, Van Nostrand Reinhold, New York.

Kayan Umar.1981. Seni, Tradisi, Masyarakat. Sinar harapan : Jakarta.

Kusmayadi dan Sugiarto, Endar 2000. Metodologi Penelitan Dalam Bidang Kepariwisataan, Jakarta ; PT. Gramedia Pustaka Utama. 
Maleong, Lexy. J 1991. Metode Kualitatif. Bandung : Remaja Rosdakarya.

Marzuki. 1997. Metodologi Riset. Yogyakarta : BPFE-UI.

Murgianto, Sal. 1992. "Kompetisi Tari". Dalam Pengantar Elemen Tari dan Beberapa Masalah Tari. Direktorat Kesenian, Proyek Pengembangan Kesenian Jakarta. Departemen Pendidikan dan Kebudayaan.

Parmi, Ni Wayan. 2005. " Tari Sanghyang Janger Maborbor di Desa Yangapi, Kabupaten Bangli. Bali" (Sebuah Kajian Budaya). (Dalam Tesis) Denpasar : Program Pasca Sarjana Universitas Udayana.

Soedarsono. 1977 : Tari-tarian Indonesia. Jakarta : Proyek Pengembangan Media Kebudayaan. Direktorat Jendral Departemen Pendidikan dan Kebudayaan.

Soedarsono, 1999 : Metode Penelitian Seni Pertunjukan dan Seni Rupa. Masyarakat Seni Pertunjukan Indonesia. Yogyakarta.

Undang-Undang Republik Indonesia No.10 Tahun 2009. Tentang Kepariwisataan.

Wahab, Salah. 2000. Tourism Management (ahli bahasa Drs Frans Gomeng : Manajemen Pariwisata). 